\title{
The Relationship among Somatotype Structures, Body Compositions and Estimated Oxygen Capacities of Elite Male Handball Players
}

\author{
İrfan MARANGOZ ${ }^{\circledR}$ \\ Sevde Mavi VAR ${ }^{2}$ (i) \\ 1.2Ahi Evran University, School of Physical Education and Sports, Krrşehir, Turkey \\ ${ }^{2}$ Email: imarangoz@ahievran.edu.tr Tel: 5066322100 \\ 'Email:sevde.mavivar@ahievran.edu.tr.Tel:5544500016
}

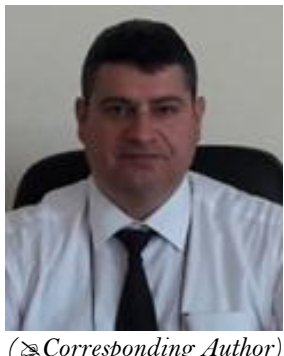

\begin{abstract}
This study aims to analyze the relationship among somatotype structures, body compositions and estimated oxygen capacities of elite male handball players in Ahi Evran University Handball Team in 2017-2018 Turkish Men's Handball First Division. It was conducted on elite male handball players $(n=15)$ aged between 18 and 30 who voluntarily participated in the study. Their arithmetic means and standard deviations are $22.06 \pm 3.80$ years of age, $186.00 \pm 7.62 \mathrm{~cm}$ height, $88.66 \pm 10.69 \mathrm{~kg}$ weight, and BMI $25.65 \pm 3.08 \mathrm{~kg} / \mathrm{m} 2$, aerobic power (VO2 max.) $41.39 \pm 3.86$ $(\mathrm{ml} / \mathrm{kg} / \mathrm{min})$, and $13.10 \% \pm 1.70 \%$ body fat. They had endomorph and mesomorph $(4.43-3.96-$ 2.14) in terms of somatotype properties. A highly negative significant correlation was found between $\mathrm{VO} 2$ max and body fat $\%(\mathrm{r}=-.702, \mathrm{p}<0.01)$, between $\mathrm{VO} 2$ max and endomorph value $(\mathrm{r}=$ $-.702, \mathrm{p}<0.01)$, and between $\mathrm{VO} 2$ max and mesomorph value $(\mathrm{r}=-.703, \mathrm{p}<0.01)$, while a highly positive significant correlation was found between $\mathrm{VO} 2 \max$ and ectomorph value $(\mathrm{r}=.609$, $\mathrm{p}<0.05)$. In conclusion, it can be stated that differences in body fat data may result from players' somatotypes categories, intensity of training, duration of training, measurements by different researchers, measurements in different periods of the season, and use of different formulas in the calculation of measurement values.
\end{abstract}

Keywords: Elite male handball players, Somatotypes, Body composition, $\mathrm{VO}_{2} \mathrm{max}$.

Citation | İrfan MARANGOZ; Sevde Mavi VAR (2018). The Relationship among Somatotype Structures, Body Compositions and Estimated Oxygen Capacities of Elite Male Handball Players. Asian Journal of Education and Training, 4(3): 216-219. History:

Received: 8 May 2018

Revised: 4 June 2018

Accepted: 6 June 2018

Published: 8 June 9018

Licensed: This work is licensed under a Creative Commons

Attribution 3.0 License (c) $)$

Publisher: Asian Online Journal Publishing Group
Contribution/Acknowledgement: Both authors contributed to the conception and design of the study.

Funding: This study received no specific financial support.

Competing Interests: The authors declare that they have no conflict of interests.

Transparency: The authors confirm that the manuscript is an honest, accurate, and transparent account of the study was reported; that no vital features of the study have been omitted; and that any discrepancies from the study as planned have been explained.

Ethical: This study follows all ethical practices during writing.

\section{Contents}

1. Introduction

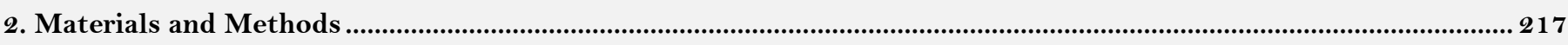

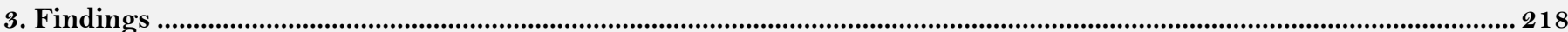

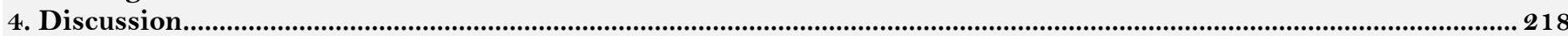

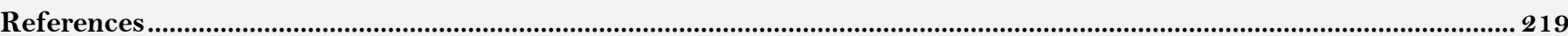




\section{Introduction}

The studies on anthropometric properties around the globe aim to identify suitable body profiles for different sports types (Çakıroğlu et al., 2002; Barış et al., 2003). Physical and physiological suitability are of vital importance in order to display a successful performance in sports. Unless the physical and physiological properties of an athlete is suitable, it is not possible for him/her to reach a satisfactory level of performance. However, physical suitability is not the only criterion for a high performance. Height, weight, body composition, aerobic and anaerobic power, strength, speed and flexibility are among factors that influence performance in sports activities (Kalyon, 1990). In addition to aerobic and anaerobic endurance, strength, cardiorespiratory, flexibility, balance, muscle and coordination, a handball player also needs to have determination, high speed and agility skills (Aktuğ et al., 2018). Similar to other sports, recent scientific and technological developments have also remarkably increased the performance of handball players (Yildirim and Özdemir, 2010) and the popularity of handball as a competitive sport as well (Eler and Bereket, 2001).

\section{Materials and Methods}

This study was conducted on elite male handball players $(n=15)$ aged between 18 and 30 in Ahi Evran University Handball Team in 2017-2018 Turkish Men's Handball First Division. Their arithmetic means and standard deviations are $22.06 \pm 3.80$ years of age, $186.00 \pm 7.62 \mathrm{~cm}$ height, $88.66 \pm 10.69 \mathrm{~kg}$ weight, and BMI $25.65 \pm 3.08 \mathrm{~kg} / \mathrm{m} 2$, aerobic power (VO2 max.) $41.39 \pm 3.86(\mathrm{ml} / \mathrm{kg} / \mathrm{min})$, and $13.10 \% \pm 1.70 \%$ body fat. They had endomorph and mesomorph $(4.43-3.96-2.14)$ in terms of somatotype properties.

\subsection{Data Collection Tools}

The somatotypes, body compositions and aerobic properties the participants were measured.

\subsection{Determination of Somatotypes}

Body weight, height, biceps and calf circumference during flexion, humerus and femur breadth, triceps, subscapular, suprailiac and calf skinfold are used to calculate somatotypes. Somatotype values are calculated using the following formulas (Ross and Marfell-Jones, 1991; Carter, 2002). They were calculated in SOMATOTURK Calculation Program (Marangoz and Özbalcı, 2017).

\subsubsection{Calculation of Endomorph}

$\mathrm{A}=$ triceps + subscapular + suprailiac

$\mathrm{B}=(170.18 /$ height $)$ (Adjustment coefficient for height)

Adjusted sum $\mathrm{X}=\mathrm{A} . \mathrm{B}$

Endomorph $=-0.7182+0.1451(\mathrm{X})-0.00068(\mathrm{X} 2)+0.0000014(\mathrm{X} 3)$

\subsubsection{Calculation of Mesomorph}

Mesomorph $=(0.858 \mathrm{HB}+0.601 \mathrm{FB}+0.188 C A G+0.161 C C G)-(0.131 \mathrm{H})+4.5$

HB: Humerus breadth $(\mathrm{cm})$

FB: Femur breadth $(\mathrm{cm})$

CAG: Arm circumference during flexion - Triceps skinfold / 10

CCG: Maximal calf circumference - Calf skinfold / 10

H: Height $(\mathrm{cm})$

\subsubsection{Calculation of Ectomorph}

Height and weight are calculated in $\mathrm{cm}$ and $\mathrm{kg}$, respectively. Height is divided by cube root of weight to calculate HWR (HWR=height/cube root of weight). Ectomorph is calculated based on HWR value using one of the formulas below:

$\underline{I F H W R \geq 40.75, \text { Ectomorph }=0.732 \times H W R-28.58}$

IF $38.25<H W R<40.75$, Ectomorph $=0.463 \times H W R-17.63$

IF $H W R \leq 38.25$, Ectomorph $=0.1$

\subsection{Body Composition}

Tanita BC-601 Segmental, Japan, a bioelectric impedance analyzer, was used to calculate body composition values (body fat\%, weight and body mass index, BMI) of the handball players who participated in the study.

\subsection{Determination of Aerobic Strength ( $\mathrm{VO}_{2} \mathrm{Max}$ )}

A 12-minute running test was developed by Cooper in order to calculate an individual's aerobic capacity. It consists of a 12-minute field test developed by Balke in previous years. Cooper test is one of the most widely used field tests, and athletes are required to run as long distance as possible in 12 minutes (Banıbrata, 2013). Thus, this test was used to measure aerobic strength. Max $\mathrm{VO}_{2}$ values of the handball players were calculated using the Formula (1) below:

Estimated $\mathrm{VO}_{2} \max =$ Distance Covered $-504.9 / 44.73$

\subsection{Statistical Analysis}

After the data were analyzed using SPSS 22 software program, the descriptive statistical analysis was used to analyze running distances and the relationship among somatotype structures of elite male handball players, their body compositions and estimated oxygen capacities. 


\section{Findings}

Table-1. Average and standard deviations of the elite male handball players' demographic variables

\begin{tabular}{l|l|l}
\hline & $\mathbf{N}$ & $\mathbf{x} \pm \mathbf{s d}$ \\
\hline Age $($ years $)$ & 15 & $22,06 \pm 3,80$ \\
\hline Weight $(\mathrm{kg})$ & 15 & $88,66 \pm 10,69$ \\
\hline Height $(\mathrm{cm})$ & 15 & $186,00 \pm 7,62$ \\
\hline BMI $\left(\mathrm{kg} / \mathrm{m}^{2}\right)$ & 15 & $25,65 \pm 3,08$ \\
\hline $\mathrm{VO}_{2} \mathrm{max} .(\mathrm{ml} / \mathrm{kg} / \mathrm{min})$ & 15 & $41,39 \pm 3,86$ \\
\hline Body Fat \% & 15 & $13,10 \pm 1,70$ \\
\hline Endomorph Value & 15 & $4,43 \pm 1,24$ \\
\hline Mesomorph Value & 15 & $3,96 \pm 1,15$ \\
\hline Ectomorph Value & 15 & $2,14 \pm, 995$ \\
\hline
\end{tabular}

( \pm ) (Mean and standard deviation)

Table-2. The relationship among somatotype structures of elite male handball players, their body compositions and estimated oxygen capacities

\begin{tabular}{|c|c|c|c|c|c|c|c|c|c|}
\hline & & Years of Age & Weight & Height & BMI & $\mathrm{VO}_{2} \max$ & Body Fat \% & Endomorph & Mesomorph \\
\hline Weight & $\mathrm{r}$ & .133 & & & & & & & \\
\hline Height & $\mathrm{r}$ & .438 & .504 & & & & & & \\
\hline $\mathrm{BMI}$ & $\mathrm{r}$ & -.109 & $.770^{\text {** }}$ & -.017 & & & & & \\
\hline $\mathrm{VO}_{2} \max$ & $\mathrm{r}$ & .157 & $-.537^{*}$ & .020 & $-.584^{*}$ & & & & \\
\hline Body Fat \% & $\mathrm{r}$ & -.304 & $.518^{*}$ & -.222 & $.783^{* *}$ & $-.702^{* *}$ & & & \\
\hline Endomorph & $\mathrm{r}$ & -.346 & .417 & -.324 & $.737^{* *}$ & $-.702^{* *}$ & $.986^{* * * * *}$ & & \\
\hline Mesomorph & $\mathrm{r}$ & $-.514^{*}$ & .464 & -.255 & $.680^{* * *}$ & $-.703^{* *}$ & $.749^{* *}$ & $.742^{* *}$ & \\
\hline Ectomorph & $\mathrm{r}$ & .281 & $-.590^{*}$ & .259 & $-.942^{* * * *}$ & $.609^{*}$ & $-.805^{* * * *}$ & $-.805^{* * * *}$ & $-.750^{* * *}$ \\
\hline
\end{tabular}

**** $<<0.001,{ }^{* *} \mathrm{p}<0.01,{ }^{*} \mathrm{p}<0.05$

The relationship between somatotype structures of elite male handball players and their body compositions and estimated oxygen capacities is given in Table 2 (correlation-Pearson). The analysis indicates:

a moderate negative significant correlation $(\mathrm{r}=-.514, \mathrm{p}<0.05)$ between years of age and mesomorph value,

a highly positive significant correlation $(\mathrm{r}=.770, \mathrm{p}<0.01)$ between weight and $\mathrm{BMI}$,

a moderate negative significant correlation $(\mathrm{r}=-.537, \mathrm{p}<0.05)$ between weight and $\mathrm{VO}_{2}$ max,

a moderate positive significant correlation $(\mathrm{r}=.518, \mathrm{p}<0.05)$ between weight and body fat $\%$,

a moderate negative significant correlation $(\mathrm{r}=-.590, \mathrm{p}<0.05)$ between weight and ectomorph value,

a moderate negative significant correlation $(\mathrm{r}=-.584, \mathrm{p}<0.05)$ between $\mathrm{BMI}$ and $\mathrm{VO}_{2}$ max,

a highly positive significant correlation $(\mathrm{r}=.783, \mathrm{p}<0.01)$ between $\mathrm{BMI}$ and body fat $\%$,

a highly positive significant correlation $(\mathrm{r}=.737, \mathrm{p}<0.01)$ between BMI and endomorph value,

a highly positive significant correlation $(\mathrm{r}=.680, \mathrm{p}<0.01)$ between BMI and mesomorph value,

a highly negative significant correlation $(\mathrm{r}=-.942, \mathrm{p}<0.001)$ between $\mathrm{BMI}$ and ectomorph value,

a highly negative significant correlation $(\mathrm{r}=-.702, \mathrm{p}<0.01)$ between $\mathrm{VO}_{2}$ max and body fat $\%$,

a highly negative significant correlation $(\mathrm{r}=-.702, \mathrm{p}<0.01)$ between $\mathrm{VO}_{2}$ max and endomorph value,

a highly negative significant correlation $(\mathrm{r}=-.703, \mathrm{p}<0.01)$ between $\mathrm{VO}_{2}$ max and mesomorph value,

a highly positive significant correlation $(\mathrm{r}=.609, \mathrm{p}<0.05)$ between $\mathrm{VO}_{2}$ max and ectomorph value,

a very highly positive significant correlation $(\mathrm{r}=.986, \mathrm{p}<0.001)$ between body fat $\%$ and endomorph value,

a very highly positive significant correlation $(\mathrm{r}=.749, \mathrm{p}<0.001)$ between body fat $\%$ and mesomorph value,

a very highly negative significant correlation $(\mathrm{r}=-.805, \mathrm{p}<0.001)$ between body fat $\%$ and ectomorph value,

a very highly positive significant correlation $(\mathrm{r}=.742, \mathrm{p}<0.01)$ between endomorph and mesomorph values,

a very highly negative significant correlation $(\mathrm{r}=-.805, \mathrm{p}<0.001)$ between endomorph and ectomorph values,

a very highly negative significant correlation $(\mathrm{r}=-.750, \mathrm{p}<0.001)$ between mesomorph and ectomorph values,

\section{Discussion}

Anthropometric properties are closely related to the physical activities of an organism and decisive factors that influence an athlete's success. An individual's oxygen consumption in unit time is directly proportional to his/her aerobic capacity. Aerobic strength is the most important factor that affects performance in endurance sports. There is a strong dependence between maximal aerobic capacity and the ability to making an intense effort (Sinirkavak et al., 2004). Regular and gradually increasing controlled training can remarkably increase an individual's maximum energy consumption (Akgün, 1994).

Sinirkavak et al. (2004) state that $\mathrm{VO}_{2} \max$ values of male handball players are $32.41 \pm 1.87(\mathrm{ml} / \mathrm{kg} / \mathrm{min})$ and found a negative correlation $(\mathrm{r}=-0.52)$ between body fat percentage and maximal oxygen consumption per kilogram, which overlaps the finding ( $\mathrm{r}=-.702)$ in this study.

The amount of calories burned and oxygen consumption in a given activity will be insufficient if the amount of body fat is excessive, thus leading to a lower cardiovascular endurance and a decreasing performance (Muratl, 2003). A high amount of fatty tissues and a low amount of fat-free muscle in a body negatively influence performance in all sports containing anaerobic and aerobic training (Falk et al., 1996). Mobilization and hydrolysis of fat provide energy during a highly intense exercise (Wolfe, 1998; Smith et al., 2000).

When the body structures of handball players are observed, it can be noted that they are tall, have long arms and legs, and their body weight help them optimally use their relative strength. In addition, they also have an above-average body weight, while their body fat percentage is below average (Yildirim, 1997). Handball requires physical strength because it is a dynamic sport. Even though technical and tactical details play an important role in handball, physical properties of players are more important. Fast breaks which often occur during a handball match require a certain agility to dribble and sprint. Shooting strength and physical properties bear utmost importance in 
vertical and stride jump shots, shots while falling, shot in bending sideways and body feints (Taşkıran, 1997; Taşucu, 2002).

In the literature review, average body fat percentages of elite male handball players are given as $11.37 \%$ by Zorba et al. (1999) as $12.4 \%$ by Taşkıran and Varol (1995) as $12.84 \%$ by Vurgun et al. (2001) as $14.15 \%$ by Eler and Bereket (2001) as $15.71 \%$ by Gökdemir (1997) as $16.77 \%$ by Yildirim and Özdemir (2010) and as $18.74 \%$ by Sevim (1990). Tillaar and Ettema (2004) and Loftin et al. (1996) state body fat percentages as $16.7 \%$ and $18.9 \%$, respectively. It is evident that findings in the literature are similar to those of this study.

In conclusion, differences in body fat data in the literature may result from handball players' somatotypes categories, intensity of training, duration of training, measurements by different researchers, measurements in different periods of the season, and use of different formulas in the calculation of measurement values. Additionally, a strongly negative correlation is observed between maximal oxygen consumption and body fat percentage. We suggest that somatotypes structures of all players (all 13 categories of Endomorph, Mesomorph and Ectomorph including central ones) performing in individual and team sports be taken into account in the determination of maximal oxygen consumption capacity.

\section{References}

Akgün, N., 1994. Exercise physiology. 2nd Edn., Izmir: Ege University Printing House.

Aktuğ, Z.B., A. Dündar, F. Murathan and R. İri, 2018. The determination of the relationship between isokinetic leg strengths and agility and speed performance of elite handball players. Journal of Education and Training Studies, 6(6): 25-30. View at Google Scholar $\mid$ View at Publisher

Banıbrata, D., 2013. Estimation of maximum oxygen uptake by evaluating cooper 12-min run test in female students of West Bengal, India. Journal of Human Sport \&Exercise, 8(4): 1988-5202. View at Google Scholar

Barış, L., S. Müniroğlu, E.E. Coruh and H. Sunay, 2003. Somatotype of Turkish men's volleyball team investigation of properties. Spormeter Physical Education and Sport Sciences Journal, 8(4): 68.

Çakıroğlu, M., E. Uluçam, B.S. Cıgalı and A. Yılmaz, 2002. Eltopu players get body measurements rates. Trakya University Medical Faculty Journal, 19(1): 35-38.

Carter, J.E.L., 2002. Part 1: The heath-carter anthropometric somatotype-instruction manual. San Diego, USA: 3-4. Retrieved from htth/cmvwsomatotypeorg/Heath-Carter Manual.pdf [Accessed 31 January 2013].

Eler, S. and S. Bereket, 2001. Comparison of motoric and physiological parameters of elite Turk and foreing handball players. Gazi Journal of Physical Education and Sport Sciences, 4(4): 44-52. View at Google Scholar

Falk, B., Y. Weinstein, R. Dotan, D.A. Abramson, D. Mann-Segal and J.R. Hoffman, 1996. A treadmill test of sprint running. Scandinavian Journal of Medicine \& Science in Sports, 6(5): 259-264. View at Google Scholar

Gökdemir, Ş., 1997. Ondokuz Mayıs University men's handball and basketball team players comparison of physical and physiological parameters. Master Thesis, Ankara.

Kalyon, T.A., 1990. Sports medicine, athletic health and sports injuries. Ankara: GATA Printing House.

Loftin, M., P. Andursan, L. Lytton, P. Pittman and B. Warren, 1996. Heart rate response during handball singles match-play and selected physical fitness components of experienced male handball players. Journal of Sports Medicine Physical Fitness, 36(2): 95-99. View at Google Scholar.

Marangoz, I. and Ü. Özbalcı, 2017. Somatotype calculation program (SOMATOTÜRK). Academic Social Research Reports, 5(47): $288-293$. View at Google Scholar | View at Publisher

Muratl, S., 2003. Children and sport through the training science approach. 1st Edn., Ankara: Nobel Publishing House. pp: 164 to 165.273.

Ross, W.D. and M.J. Marfell-Jones, 1991. Kinanthropometry. In MacDougall, DJ., Wenger AH \& Green H J. (Eds), Physiological testing of the high-performance athlete. Illinois: Human Kinetics Books. pp: 223-308.

Sevim, Y., 1990. The impact of strength training on leap and shot strength in handball from sports games. Reports of the 1st National Symposium on Sports Medicine, Ankara. pp: 351-365.

Sinirkavak, G., D.A.L. Uğur and Ö. Çetinkaya, 2004. Maximal oxygen with body composition in elite sports the relationship between the capacity. Cumhuriyet University Medical Faculty Magazine, 26(4): 171-176.

Smith, T., B. Smith and M. Davis, 2000. Predictors of physical fitness in a collage sample. Perceptual Math Skills, 91(3): 1009-11 10. View at Google Scholar | View at Publisher

Taşkıran, Y., 1997. Performance on the handbag. Ankara: Bağırgan Yayınevi. 1-3: 85-86.

Taşkıran, Y. and R. Varol, 1995. Fast attacking wing and internal defense after offensive and defensive defense the players are $30 \mathrm{~m}$. Comparison of Sprint Values, Performance Magazine, İzmir, 1(1): 25-29.

Taşucu, E., 2002. Determination of the somatotype profile of Turkish men handball national team. Master Thesis. Ankara, 1- 5, 10-23, 72.

Tillaar, R. and G. Ettema, 2004. Effect of body size and gender in overarm throwing performance. European Journal of Applied Physiology, 91(4): 413-418. View at Google Scholar $\mid$ View at Publisher

Vurgun, H., S. Bereket and R. Varol, 2001. According to elite female-male handball players position examination of physical and physiological characteristics. Journal of Gazi Physical Education and Sport Sciences, 6(2): $11-22$.

Wolfe, R.R., 1998. Fat metabolism in exercise. In skeletal muscle metabolism in exercise and diabetes. Boston, MA: Springer. pp: 147-156.

Yildirim, İ. and V. Özdemir, 2010. The influence of anthropometric characteristics of senior male handball players on horizontal and ver tical jump spacing. Selçuk University Physical Education and Sports Science Journal, 12(1): 58-67.

Yildirim, K., 1997. Some motoric and anthropometric features of the male handball national team players evaluation. Graduate Thesis, Ankara. pp: 9-17.

Zorba, E., M.A. Ziyagil, G.K. Yıldırım and İ. Erdemir, 1999. Assessment of motoric and anthropometric characteristics of male handball national team. Turkish Sports Medicine Congress Abstract Book, Antalya. 